\title{
INDONESIAN OIL PALM EXPORT MARKET SHARE AND COMPETITIVENESS TO EUROPEAN UNION COUNTRIES: IS THE ROUNDTABLE ON SUSTAINABLE PALM OIL (RSPO) INFLUENTIAL?
}

\author{
Hansen Tandra ${ }^{*}$, Arif Imam Suroso ${ }^{* * 1}$, Yusman Syaukat*), Mukhamad Najib ${ }^{* * *}$ \\ ${ }^{*}$ Department of Resources and Environmental Economics, Faculty of Management and Economics, IPB University \\ Jl. Agatis, Dramaga, Bogor, 16680 Indonesia \\ ${ }^{* *}$ School of Business, IPB University \\ Jl. Pajajaran Road, Bogor, 16151 Indonesia \\ *Department of Management, Faculty of Management and Economics, IPB University \\ Jl. Agatis, Dramaga, Bogor, 16680 Indonesia
}

\begin{abstract}
The European Union is one of the main export destinations for Indonesian palm oil. However, this area requires the sustainable development of palm oil products. Four countries from the European Union region are consistently export destinations for palm oil: Netherlands, Italy, Germany and Spain. RSPO exists as one of the institutions that ensure sustainable development in palm oil production. This study aims to analyze whether there were differences before and after implementation of RSPO in export market share and the competitiveness of CPO and RPO exports to the Netherlands, Italy, Germany, and Spain. The analysis was carried out during 1995-2020 using the paired sample t-test and the Wilcoxon signed-rank test. The analysis results show that there are differences in the export market share and competitiveness of Indonesian CPO exports to the Netherlands, Italy, Spain and Germany. The same finding was also found in RPO, especially in Indonesia's export market share. However, there is no difference in the export market share and competitiveness of Indonesian RPO exports to the Netherlands before and after implementing the RSPO in 2008.
\end{abstract}

Keywords: european union, export market share, export competitiveness, palm oil

\begin{abstract}
Abstrak: Uni Eropa merupakan salah satu pasar tujuan utama ekspor minyak sawit Indonesia. Namun, kawasan ini mewajibkan adanya pengembangan berkelanjutan pada produk kelapa sawit. Empat negara dari kawasan Uni Eropa secara konsisten menjadi tujuan ekspor minyak sawit: Belanda, Italia, Jerman, dan Spanyol. RSPO hadir sebagai salah satu lembaga yang menjamin pembangunan berkelanjutan dalam produksi minyak sawit. Penelitian ini bertujuan menganalisis apakah terdapat perbedaan sebelum dan sesudah implementasi RSPO pada pangsa pasar ekspor dan daya saing ekspor CPO dan RPO ke Belanda, Italia, Jerman, dan Spanyol. Analisis dilakukan selama 1995-2020 menggunakan uji t sampel berpasangan dan uji peringkat bertanda Wilcoxon. Hasil analisis menunjukkan bahwa terdapat perbedaan pangsa pasar ekspor dan daya saing ekspor CPO Indonesia ke Belanda, Italia, Spanyol dan Jerman. Temuan yang sama juga ditemukan pada RPO, khususnya pada pangsa pasar ekspor Indonesia. Namun demikian, tidak terdapat perbedaan pangsa pasar ekspor dan daya saing ekspor RPO Indonesia ke Belanda sebelum dan sesudah penerapan RSPO pada tahun 2008.
\end{abstract}

Kata kunci: uni eropa, pangsa pasar ekspor, daya saing ekspor, minyak sawit

\footnotetext{
${ }^{1}$ Corresponding author:

Email: arifimamsuroso@apps.ipb.ac.id
} 


\section{INTRODUCTION}

Palm oil is one of Indonesia's most potential plantation commodities to increase the surplus in international trade. Based on the Ministry of Agriculture (2021), oil palm is a agriculture commodity with the highest export contribution for Indonesia with 28.279 million tons. The demand for palm oil will proceed to rise along with the benefits of food, cosmetics, and energy needs. The other benefit of industrial-based oil palm development is that it creates a source of employment that can increase the standard of living and household income of oil palm farmers (Suroso and Ramadhan, 2014; Tandra et al. 2021). Although oil palm has an essential role in the national economy, issues related to sustainability resulting from palm oil production have created polarization in recent years for policymakers and companies (Vergura et al. 2019). The sustainable issue could be an investment in the stock market with indicators of the adoption of sustainable certification (Suroso et al. 2021).

The opening of the palm oil industry is often a debate in every developing country, including Indonesia. Debates that often arise are environmental issues such as air pollution, land displacement, and deforestation, which have implications for reducing biodiversity globally (Oosterveer, 2015; Saswattecha et al. 2015). In addition to environmental issues, oil palm creates social conflict within the community (Rist et al. 2010). As a result, consumers' concern indirectly affects their purchasing preferences (Antone and Spencer, 2014). In overcoming this issue, sustainable certification was developed through the Roundtable on Sustainable Palm Oil (RSPO) to implement the sustainable practice standards in palm oil industry. Since 2008, 102 countries have participated in the RSPO with a total of 460.014 ha of certified land and 162,861 individual smallholders registered as RSPO members (RSPO 2021). Therefore, exporting countries participate in RSPO sustainable certification to enter the market in certain countries. Sustainable certification from the RSPO has now developed into a requirement for entry to export destination countries. The European Union region is the main of Indonesia palm oil export destinations. The European Union countries that continued to import palm oil from Indonesia during the 1995-2020 period were the Netherlands, Spain, Italy and Germany. In addition, these countries hint at the sustainable certification of palm oil for use. However, the costs for implementing sustainable certification are not matched by the profits obtained, so that it is only a responsibility to the environment (Salman et al. 2017). The main palm oil-producing countries have a vital role in the bargaining process in implementing the RSPO because they can hinder the entry of imports into export destination countries (Erman, 2018). Therefore, it is necessary to analyze palm oil export market share and competitiveness to European Union countries.

Several previous studies are discussing the RSPO and its impact on the palm oil trade globally. Rosyadi et al. (2020) found that the RSPO was found to have a positive and significant effect on Indonesia's CPO exports to major export destination countries. While Ali et al. (2020) found that there were differences in the Indonesia CPO export value to India and the United States markets before the implementation of RSPO in export destination countries, but there was no difference in export competitiveness. Ali et al. (2021) analyze the export performance and competitiveness of the CPO industry with the RSPO in China and the European Union Market. The finding is that there is no distinct in export value, but there is a distinct in export competitiveness in China and the European Union Market. The ownership of RSPO certification is also one aspect that influences the export decisions of palm oil companies in Indonesia and Malaysia (Maretna et al. 2021). The difference of this study compared to previous studies is the focus of the European Union market, which is more specific in four countries, namely the Netherlands, Germany, Italy and Spain. Figure 1 shows these only four European Union countries have a consistent and higher export performance than other European Union Countries from 1995 to 2020 (UNComtrade, 2021).

Additionally, the observation period used is before and after the RSPO was implemented in 2008 (Rosyadi et al. 2020). It was also the first year that certified sustainable palm oil goods were shipped (RSPO, 2021). The identification of the RSPO Legitimacy as one of the world's largest providers of sustainable certificates for palm oil. RPO was also tested in this study because of the RSPO sustainability certification label found on palm oil products in European Union countries. This study aimed to analyze the differences in export market share and export competitiveness of Indonesian palm oil before and after implementing the RSPO in 2008. 


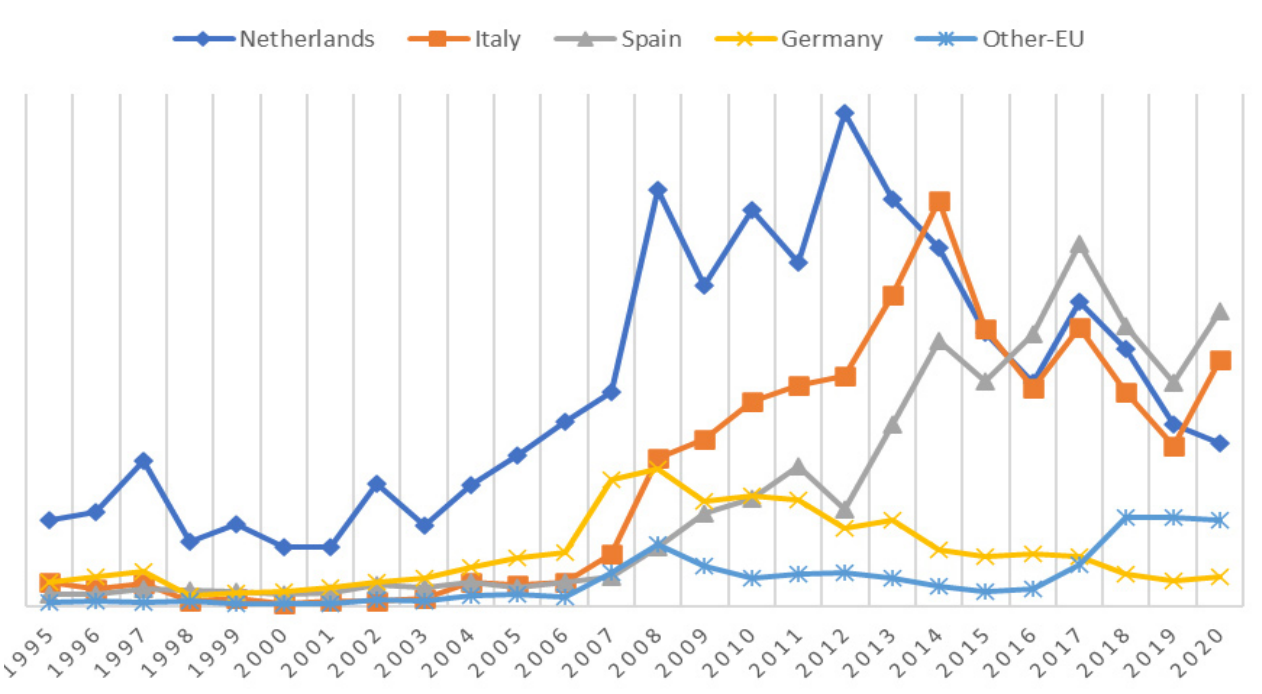

Figure 1. The trend of Indonesia export performance with European Union Countries (UNComtrade, 2021)

\section{METHODS}

The source of this study comes from United Nations Comtrade (UNComtrade) related to export market share and export competitiveness of CPO (HS code 151110) and RPO (HS code 151190). This study uses a descriptive approach and quantitative analysis to determine whether there are differences in the Indonesia export market share and export competitiveness of $\mathrm{CPO}$ and RPO to European Union countries. The list of EU countries used is the Netherlands, Germany, Italy and Spain. This was chosen because these countries continued to be the destination countries for palm oil exports in Indonesia during the period 1995-2020 (n $=26$ ). The data used are time series, namely annual data. The market share of $\mathrm{CPO}$ and RPO exports is measured by the value of exports from Indonesia to European Union countries divided by the total value of world CPO and RPO exports. It differs from other indicators because it evaluates a country's export market for a particular commodity compared to world exports. The formula for the export market share index is as follows:

$$
\mathrm{EMS}=\mathrm{X}_{\mathrm{it}} / \mathrm{X}_{\mathrm{wt}}
$$

Where: EMS - palm oil export market share of country $i$ in year $t$; Xit - palm oil exports of country $i$ in year $\mathrm{t}$ (CPO and RPO) ; Xwt - world palm oil exports at time $\mathrm{t} ; \mathrm{i}$ - Total exports of Indonesia to the Netherlands Italy Spain and Germany, w - Total World Exports. The competitiveness of Indonesian CPO and RPO exports was assessed using the Revealed Symmetric
Comparative Advantage (RSCA) approach. The Revealed Comparative Advantage (RCA) index was first introduced by Balassa (1965) to define the comparative advantage or disadvantage index of exports to specific countries. The approach compares the share of a country's exports in total exports to the share of the focused country's exports in total exports. The formula for RCA is as follows:

$$
\mathrm{RCA}=\left(\mathrm{X}_{\mathrm{ij}} / \mathrm{X}_{\mathrm{iw}}\right) /\left(\mathrm{X}_{\mathrm{wj}} / \mathrm{X}_{\mathrm{w}}\right)
$$

Where: $\mathrm{X}$ refers for exports, i refers for a specific country, $\mathrm{j}$ is for a specific product, $\mathrm{t}$ is a group of products, and $\mathrm{n}$ is for a group of countries. The Balassa Index has been criticized for lacking to estimate the impact of agricultural trade policies by displaying unequal values. The trade structural is distorted by various country actions and trade barriers. At the same time, if a country has a comparative advantage, the RCA index's asymmetric value might range from one to indefinitely. Dalum et al. (1998) transformed the RCA index to produce the revealed symmetrical comparative advantage (RSCA) index, which was represented as a linear transformation of the RCA index as follows:

$$
\mathrm{RSCA}=(\mathrm{B}-1) /(\mathrm{B}+1)
$$

The RSCA ranges between 1 and 1 , with values between 0 and 1 describing the comparative export advantage. Otherwise, the values between 1 and 0 describing comparative export losses. Since the distribution of RSCA is approximately zero, the potential bias can be avoided. 
The quantitative analysis in this study is comparative analysis with paired sample t-test and Wilcoxon Signed rank test. This technique is used to examine data that are interconnected, but treated differently through the observation period. The determination of the use of analytical techniques is done by testing the distribution of data through One Kolmogorov-Smirnov. A comparative analysis was conducted to test if there are significant differences or not for the export to European countries before and after the RSPO implementation. The data in this study used for 26 years from 19952020. Meanwhile, to answer the study inquiry of whether there is an influence of RSPO on Indonesian exports to European Union countries, data before the RSPO for the 1995-2007 period and after the RSPO for the 2008-2020 period are used.

\section{RESULTS}

The description analysis shows the export market share and competitiveness of CPO and RPO. Figure 2 and Figure 3 show the market share of $\mathrm{CPO}$ and RPO exports, respectively. It can be seen that the market share of Indonesia's CPO exports tends to fluctuate in four countries in the European Union. Spain was the country's highest export destination for Indonesian CPO in 2020. Meanwhile, the highest market share for Indonesian RPO exports in 2020 came from Italy.
However, the Netherlands has almost always been the main market destination for Indonesian $\mathrm{CPO}$ and RPO during the period. Germany is the destination country for Indonesia's CPO and RPO exports with the lowest export market share compared to the other three European Union countries. The implementation of the RSPO since 2008 shows a decline in the market share of CPO and RPO exports in four European Union countries from 2009-2013. However, the export market share after 2014 in the Netherlands, Italy and Germany has decreased.

It can be an indirect impact from non-tariff barriers that start to be applied for Indonesian palm oil products and implicate trading in Europe (Dharmawan and Sarianti 2015). A description of the RSCA of CPO and RPO with four European Union countries are shown in Figure 4 and Figure 5. Spain and the Netherlands. However, the Indonesia $\mathrm{CPO}$ exports competitiveness to Netherlands is more stable than the three export destination countries in the European Union. Meanwhile, the competitiveness of Indonesian RPO exports tends to be high in Spain and the Netherlands during the research observation period. The competitiveness of Indonesian CPO and RPO exports to Germany tends to fluctuate. The implementation of the RSPO since 2008 has not shown an increase in the Indonesia CPO and RPO exports competitiveness against the four European Union countries.

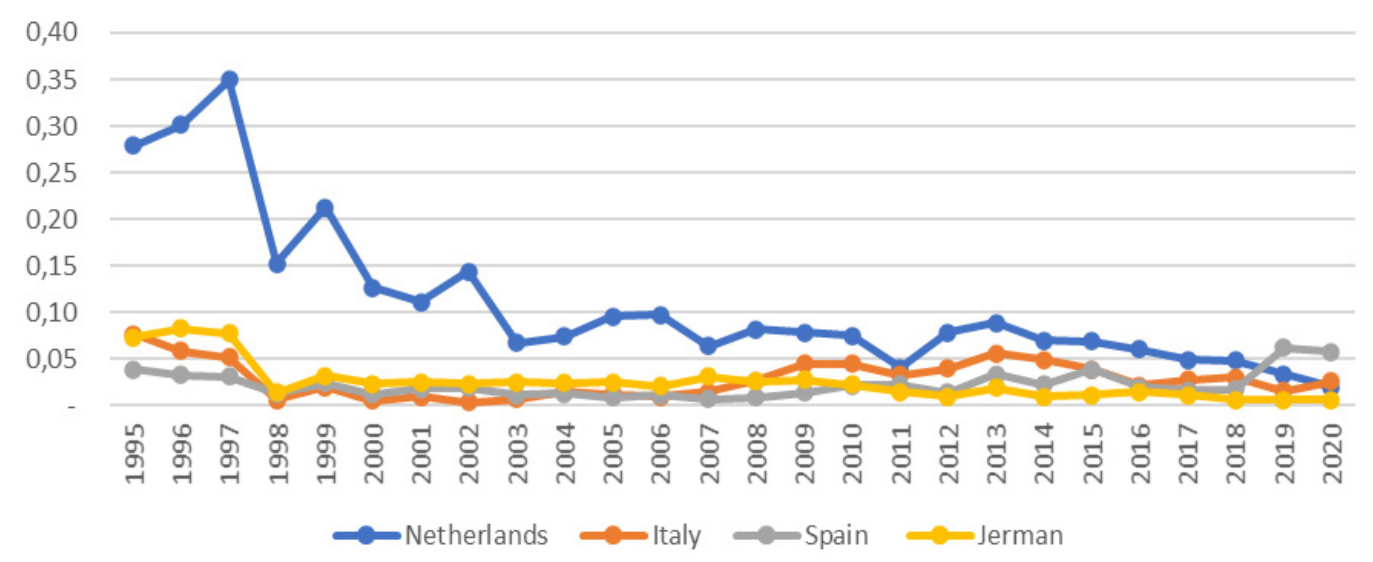

Figure 2. Indonesia CPO export market share to four european countries (UNCOMTRADE, 2021) 


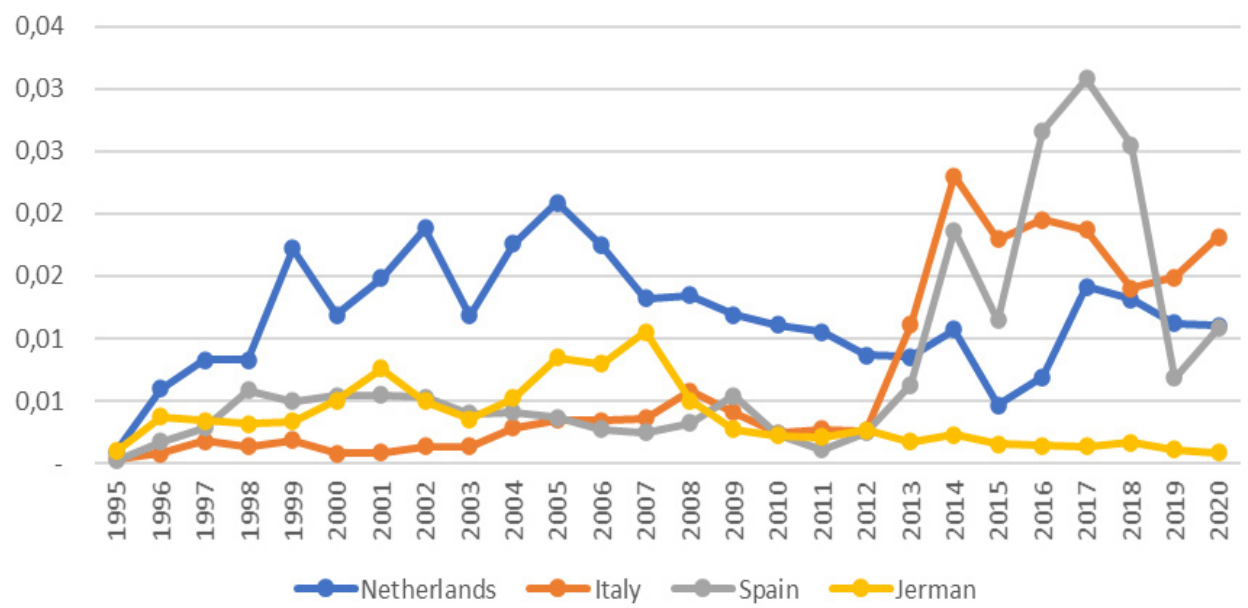

Figure 3. Indonesia RPO export market share to four european countries (UNCOMTRADE, 2021)

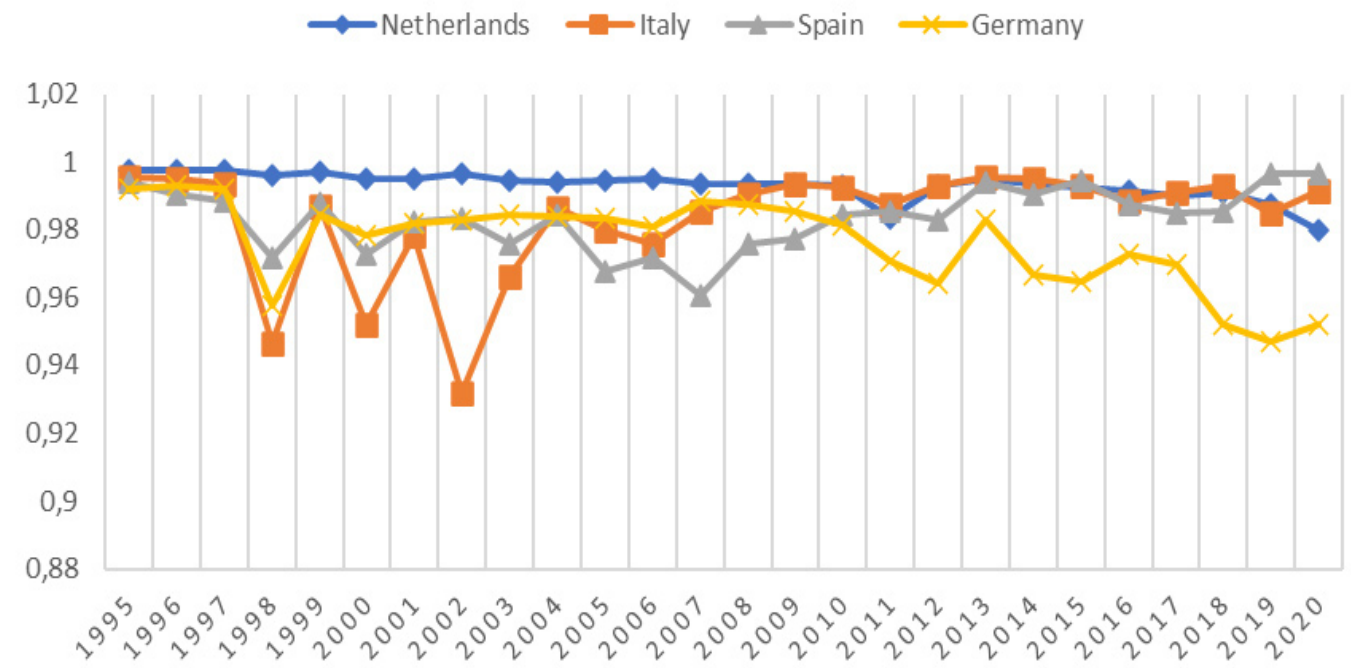

Figure 4. The RSCA of Indonesia CPO to Four European Countries (UNComtrade, 2021)

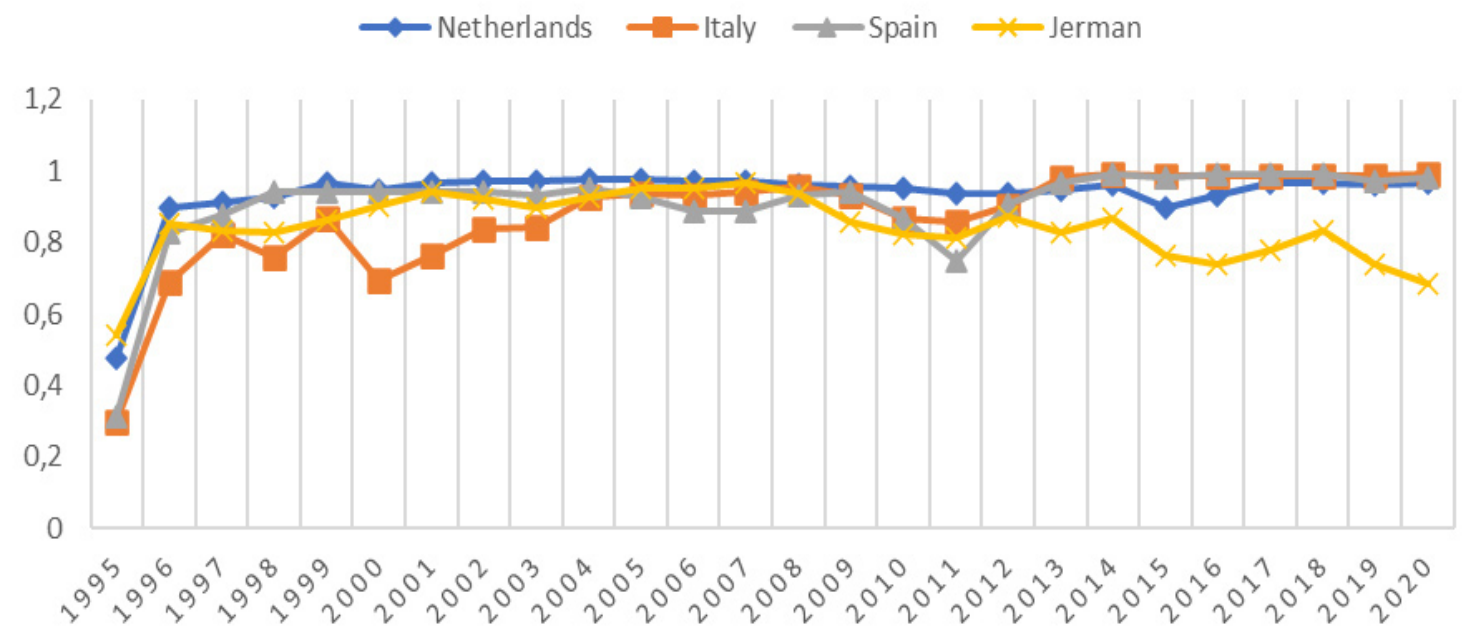

Figure 5. The RSCA of Indonesia RPO to four european countries (UNCOMTRADE, 2021) 
Table 1 reveals the results of the data distribution test on $\mathrm{CPO}$ and RPO via Kolmogorov-Smirnov. The results of the distribution test showed that only the RSCA data on CPO in Spain were usually distributed. Meanwhile, in the RPO data distribution test, the RPO export value data in the Netherlands and the RPO RSCA data in Germany showed a normal distribution. The normal data distribution was continued in the paired sample t-test. While the other data did not show a normal distribution, it was continued in the Wilcoxon signedrank test. Table 2 and Table 3 respectively show the comparative test results through the paired sample t-test and the Wilcoxon signed-rank test. The comparative test results show that there are differences in the export market shares in the Netherlands and Germany in the period before and after the implementation of the RSPO in 2008 .

The results of other comparative tests also show distinct for CPO exports competitiveness in the Netherlands, Italy, Spain and Germany. There are palm oil import substitutes in Europe that are competitive in the European Union massively, namely: soybean oil (Sudaric et al. 2019). It will be affected the export performance and implicate competitiveness. However, there was no difference in the CPO export market share in Italy and Spain. The other research shows that Italy and Spain are rising star positions, so the Indonesia palm oil export is ideal (Khairunisa and Novianti, 2017).

The RPO testing results showed differences in the export market share in Italy, Spain, and Germany before and after implementing the RSPO in 2008. Meanwhile, RPO Competitiveness in Italy and Spain shows the difference before and after implementing the RSPO in 2008. On the other hand, there was no difference in the RPO export market share and RSCA in the Netherlands. The results found that the presence of the RSPO had an impact on the export market share and Indonesia CPO exports competitiveness to the Netherlands, Italy, Germany and Spain.

Table 1. The Normality Test

\begin{tabular}{llcccc}
\hline & Netherlands & Italy & Spain & Germany \\
\hline CPO & Export Market Share & 0.254 & 0.129 & 0.195 & 0.267 \\
& & $(0.000)$ & $(0.200)$ & $(0.013)$ & $(0.000)$ \\
& RSCA & 0.213 & 0.268 & $0.155^{*}$ & 0.217 \\
& & $(0.004)$ & $(0.000)$ & $(0.112)$ & $(0.003)$ \\
\multirow{2}{*}{ RPO } & Export Market Share & $0.095^{*}$ & 0.300 & 0.312 & 0.180 \\
& & $(0.200)$ & $(0.000)$ & $(0.000)$ & $(0.030)$ \\
& \multirow{2}{*}{ RSCA } & 0.327 & 0.218 & 0.268 & $0.148^{*}$ \\
& & $(0.000)$ & $(0.003)$ & $(0.000)$ & $(0.150)$ \\
& Observation & 26 & 26 & 26 & 26 \\
\hline
\end{tabular}

Note $: *=$ The distribution data is normal

Table 2. The Comparative Results (CPO)

\begin{tabular}{lcccc}
\hline Variables & Netherlands & Italy & Spain & Germany \\
\hline Export Market Share & $-3.180^{* * *}$ & -1.734 & -0.943 & $-3.110^{* * *}$ \\
& $(0.001) \mathrm{a}$ & $(0.108) \mathrm{b}$ & $(0.345) \mathrm{a}$ & $(0.002) \mathrm{a}$ \\
\multirow{2}{*}{ RSCA } & $-3.180^{* * *}$ & $-2.760^{* * *}$ & $-1.860^{*}$ & $-2.691^{* * *}$ \\
& $(0.001) \mathrm{a}$ & $(0.006) \mathrm{a}$ & $(0.088) \mathrm{b}$ & $(0.007) \mathrm{a}$ \\
\hline
\end{tabular}

*,**,**: Significance at $10 \%, 5 \%$ and $1 \%$; a : Based on wilcoxon signed ranks test; $\mathrm{b}:$ Based on paired sample t-test 
Table 3. The Comparative Results (RPO)

\begin{tabular}{llccc}
\hline Variables & Netherlands & Italy & Spain & Germany \\
\hline Export Market Share & -1.254 & $-3.180^{* * *}$ & $-2.411^{* * *}$ & $-2.551^{* * *}$ \\
& $(0.234) \mathrm{b}$ & $(0.001) \mathrm{a}$ & $(0.016) \mathrm{a}$ & $(0.011) \mathrm{a}$ \\
\multirow{2}{*}{ RSCA } & -0.245 & $-3.180^{* * *}$ & $-2.062^{* *}$ & 1.409 \\
& $(0.807) \mathrm{a}$ & $(0.001) \mathrm{a}$ & $(0.039) \mathrm{a}$ & $(0.184) \mathrm{b}$ \\
\hline
\end{tabular}

$*, * *, * *:$ Significance at $10 \%, 5 \%$ and $1 \%$; a : Based on wilcoxon signed ranks test; $\mathrm{b}:$ Based on paired sample $\mathrm{t}$-test

This is in contrast to the findings by Ali et al. (2021) who did not find any differences in CPO exports to China and the European Union market. The implementation of the RSPO in the European Union is carried out by 11 countries with a commitment to only import palm oil that has been certified sustainable (Tey et al. 2020). This is an absolute requirement for major palm oil exporting countries including Indonesia to be able to enter the market in European Union countries. The findings of this study also show that the RSPO has a strong role in influencing the export market share and export competitiveness of Indonesian palm oil products as a whole, especially the European Union. Sustainable certification from RSPO required for exporting destination countries is a form of non-tariff barrier with long processing times and high payments (Narjoko, 2015). Therefore, export market share and export competitiveness may decrease along with the difficulty of entering export destination countries that apply this certification.

The European Union have implemented sustainable development through the use of environmentally friendly energy to develop the Renewable Energy Directive (RED) policy which was published in 2009. Although EU countries' adoption of the RSPO has only recently been implemented in 2012, sustainability aspects were considered by the Netherlands, Germany Italy and Spain with the participation of the RSPO in 2008 (RSPO, 2021). Furthermore, RED II was also developed in 2019 and will be started in January 2024 by specifying palm oil as an unsustainable energy raw material. The RED regulation is considered a trade barrier for Indonesian palm oil in certain limit (Widyatmoko, 2015). In this research, RSPO can be seen as a form of trade barrier for limited restrictions. It will implicate the decreasing in palm oil market position of Indonesian palm oil to European Union countries which are the main destination countries for palm oil exporters, namely the Netherlands, Germany, Italy and Spain to reconsider products made from palm oil. However, this trade barrier could be solved by market expansion to other countries with low export market share (Rifin, 2010)

\section{Managerial Implications}

This study found that there are distinct results in the market share and competitiveness of Indonesian CPO and RPO exports from the Netherlands, Italy, Germany and Spain. The other sustainable issues such as animal health and protection are also considered to hinder the entry of Indonesian palm oil into Europe, so palm oilbased products are avoided. However, other findings from this study regarding the export market share and competitiveness of Indonesian RPO exports to the Netherlands did not show any difference before and after the presence of the RSPO. RPO is also main exporter commodities in Netherlands. Furthermore, it could be an opportunity for Indonesia to remain collaborate with Netherlands in RPO trade.

\section{CONCLUSIONS AND RECOMMENDATIONS}

\section{Conclusions}

Overall, the RSPO has a different influence on EU countries. The export market share of Indonesia's $\mathrm{CPO}$ and RPO to four European Union countries (Netherlands, Italy, Spain and Germany) was found to fluctuate during the period 1995-2020. However, the CPO export market share tends to experience a decline in the export market share during the observation period. Meanwhile, the Indonesia CPO and RPO exports competitiveness did not show any improvement and tends to fluctuate. 
This study shows that the implementation of the RSPO in 2008 had an impact on the export share and competitiveness of CPO and RPO exports in several European Union countries. There are differences in the export market share and competitiveness of Indonesian $\mathrm{CPO}$ exports to Italy, Spain and Germany. The same finding was also found in RPO, especially the export market share. However, there is no distinct in the export market share and competitiveness of Indonesian RPO exports to the Netherlands both before and after the implementation of the RSPO in 2008.

\section{Recommendations}

Based on the findings, there are some recommendations for policymakers such as: 1) the export expansion to destination countries with low export market share, 2) preserve a good diplomatic relation with countries in Europe, especially the Netherlands, Italy, Spain and Germany, 3) promote the palm oil as an environmentally friendly source of energy and 4) the adaption of the EU palm oil market by practicing sustainable palm oil development. Thus, the goal of these policies to extend an export market share and increase the competitiveness of palm oil in the global market.

\section{ACKNOWLEDGEMENT}

The authors would like to thank for Ministry of Education and Culture, Directorate General of Higher Education of the Republic of Indonesia as an organization to funding this research with the scheme of "Penelitian Pendidikan Magister Menuju Doktor untuk Sarjana Unggul" (PMDSU) based on decree letter (09/E1/KPT/2021) with contract number : 077/E4.1/AK.04.PT/2021.

\section{REFERENCES}

Ali H, Karimi, Febriamansyah R. 2020. Analysis of export performance and export competitiveness trade of crude palm oil [CPO] industry in Indonesia with RSPO in India and United States markets. In IOP Conference Series: Earth and Environmental Science 497(1): 012043. https:// doi.org/10.1088/1757-899X/769/1/012043

Alii H, Karimi S, Febriamansyah R. 2021. Export performance and export competitiveness of Indonesia's CPO industry with RSPO in China and EU markets. In IOP Conference Series: Earth and Environmental Science 741(1): 012073. https:// doi.org/10.1088/1755-1315/741/1/012073

Antone SD, Spencer R. 2014. Organising for sustainable palm oil consumption : a market based approach. Consumption Markets and Culture 18(5): 55-71. https://doi.org/10.1080/10253866.2014.899217

Balassa B. 1965. Trade liberalisation and "revealed" comparative advantage 1. The manchester school 33(2): 99-123. https://doi.org/10.1111/ j.1467-9957.1965.tb00050.x

Dalum B, Laursen K, Villumsen G. 1998. Structural change in OECD export specialisation patterns: de-specialisation and 'stickiness'. International Review of Applied Economics 12(3): 423-443. https://doi.org/10.1080/02692179800000017

Dharmawan D, Sarianti T. 2015. Indonesia's crude palm oil (CPO) againts black campaign. The Macrotheme Review 4(5): 59-80

Erman E. 2018. Dibalik keberlanjutan sawit: aktor, aliansi dalam ekonomi politik sertifikasi uni eropa. Masyarakat Indonesia 43(1).

Khairunisa GR, Novianti T. 2017. Daya saing minyak sawit dan dampak renewable energy directive (RED) Uni Eropa terhadap ekspor Indonesia di pasar Uni Eropa. Jurnal Agribisnis Indonesia (Journal of Indonesian Agribusiness) 5(2): 125136. https://doi.org/10.29244/jai.2017.5.2.125136

Maretna PA, Mulyati H, Cahyadi ER, RahmanAA. 2021. The effect of sustainable palm oil certification on export and downstream industry development (Indonesia-Malaysia Case). Proceedings of the 1st International Conference on Sustainable Management and Innovation, ICoSMI 2020, Bogor : 14-16 September 2020. https://doi. org/10.4108/eai.14-9-2020.2304448

Ministry of Agriculture. 2021. Indonesian Plantation Statistics 2019-2021. Jakarta: Ministry of Agriculture.

Narjoko, D. 2015. AEC blueprint implementation performance and challenges: non-tariff measures and non-tariff barriers. ERIA Discussion Paper Series (2015-36).

Oosterveer, P. 2015. Promoting sustainable palm oil: viewed from a global networks and flows perspective. Journal of Cleaner Production 107: 146-153.https://doi.org/10.1016/j. jclepro.2014.01.019

Rifin, A. 2010. Export competitiveness of Indonesia's palm oil product. Trends in Agriculture Economics 3(1): 1-8. https://doi.org/10.3923/ tae.2010.1.18 
Rist L, Feintrenie L, Levang P. 2010. The livelihood impacts of oil palm: smallholders in Indonesia. Biodiversity and Conservation 19(4): 10091024

Rosyadi FH, Darwanto DH, Mulyo JH. 2020. Impact of Roundtable on Sustainable Palm Oil (RSPO) certification on the Indonesian CPO exports to the destination countries. Jurnal Agro Ekonomi 31(1):1-13. https://doi.org/10.22146/ ae.54559

RSPO. 2021. About. https://rspo.org/about, [13 Sept 2021].

RSPO. 2021. Member. https://rspo.org/members/all, [13 Sept 2021].

Salman F, Najib M, Djohar S. 2017. Cost and Benefit Analysis of RSPO Certification (Case Study in PT BCA Oil Palm Plantation in Papua). Indonesian Journal of Business and Entrepreneurship (IJBE) 3(3): 219-219. https://doi.org/10.17358/ ijbe.3.3.219

Saswattecha K, Kroeze C, Jawjit W, Hein L. 2015. Assessing the environmental impact of palm oil produced in Thailand, Journal of Cleaner Production 100: 150-169. https://doi. org/10.1016/j.jclepro.2015.03.037

Sudarić A, Kočar MM, Duvnjak T, Zdunić Z, Kulundžić AM. 2019. Improving seed quality of soybean suitable for growing in Europe. Soybean for Human Consumption and Animal Feed.
Suroso AI, Ramadhan A. 2014. Structural path analysis of the Influences from smallholder oil palm plantation toward household income: one aspect of e-Government initative. Advanced Science Letters 20(1): 352-356. https://doi.org/10.1166/ asl.2014.5317

Tandra H, Suroso A, Najib M, Syaukat Y. 2021. The effect of COVID-19 in European union on the performance of Indonesian publicly listed palm oil companies. Accounting 7(4): 801-808. https://doi.org/10.5267/j.ac.2021.2.004

Tey YS, Brindal M, Darham S, Sidique SF A, Djama, M. 2020. Early mover advantage in Roundtable on Sustainable Palm Oil certification: A panel evidence of plantation companies. Journal of Cleaner Production 252: 119775. https://doi. org/10.1016/j.jclepro.2019.119775

UNComtrade. 2021. UN Comtrade Database. https:// comtrade.un.org/ [13 Sept 2021].

Vergura DT, Zerbini C, Luceri B. 2019. Palm oil free" vs "sustainable palm oil" : the impact of claims on consumer perception. British Food Journal 121(9): 2027-2035. https://doi.org/10.1108/ BFJ-01-2019-0020

Widyatmoko B. 2015. Exploring the European Union Renewable Energy Directive and its Implications for Indonesias Palm Oil Industry. Journal of Indonesian Social Sciences and Humanities 5(1): 27-38. https://doi.org/10.14203/jissh.v5i1.24 